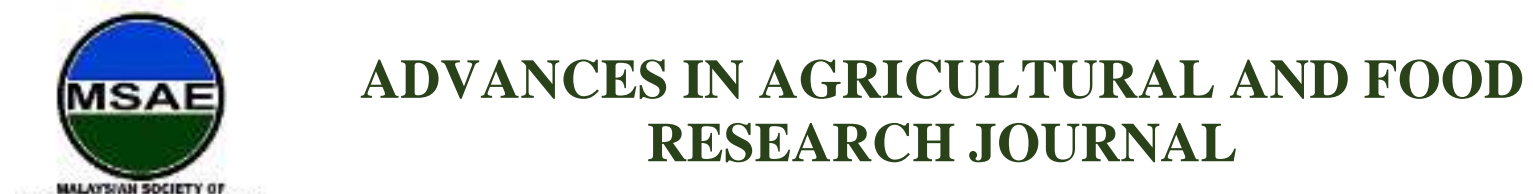

Original Research Article

\title{
Nutritional Properties of Orange-Fleshed Sweet Potato Juice
}

Nurul Ainina Zulkifli ${ }^{1}$, Nurhanisah Mohammed Salleh ${ }^{1}$, Mohd Zuhair Mohd Nor ${ }^{1,2 *}$, Farah Nadia Omar ${ }^{1}$, Alifdalino Sulaiman ${ }^{1}$, Mohd Noriznan Mokhtar ${ }^{1}$

${ }^{1}$ Department of Process and Food Engineering, Faculty of Engineering, Universiti Putra Malaysia, 43400 Serdang, Selangor, Malaysia

${ }^{2}$ Laboratory of Halal Science Research, Halal Products Research Institute, Universiti Putra Malaysia, 43400 Serdang, Selangor, Malaysia

**Corresponding author: Mohd Zuhair Mohd Nor, Department of Process and Food Engineering, Faculty of Engineering, Universiti Putra Malaysia, 43400 Serdang, Selangor, Malaysia; zuhair@upm.edu.my

Abstract: Orange-fleshed sweet potato (OFSP) offers many health benefits and can be processed into different food forms including as a healthy drinking juice. However, the OFSP juice requires exploration on the juice properties, especially its nutritional elements before it can be marketed as a healthy drink. Hence, this study aims to address the detailed nutritional composition of the OFSP juice via analyses of proximate composition, amino acids, mineral, carotenoids and vitamins. Findings have shown that OFSP juice is proven to be high in beta-carotene with a value of $4916.06 \mu \mathrm{g} / \mathrm{L}$ which is almost 100 times the value of beta-carotene in orange juice, and also rich in vitamins, certain amino acids and minerals. By considering that, these phytochemicals can aid in the reduction of anti-mutagenic, immuno-enhancers, cancer, and free radical scavengers, in which this study has proven the potential of OFSP to be processed into a healthy juice based on its nutritional properties.

Keywords: Ipomoea batatas (L.) Lam; orange-fleshed sweet potato; carotenoid; healthy drinking juices

Received: $25^{\text {th }}$ April 2020

Accepted: $14^{\text {th }}$ August 2020

Published: $28^{\text {th }}$ August 2020

Citation: Zulkifli NA, Salleh NM, Nor MZM, et al. Nutritional properties of orange-fleshed sweet potato juice. Adv Agri Food Res J 2020; 1(1): a0000104. https://doi.org/10.36877/aafrj.a0000104

\section{Introduction}

Fruits and vegetables are rich in nutrients and are considered vital for mankind which can help people who suffer from nutrient deficiency. Many people suffer from premature mortality and disability due to the low fruit and vegetable consumption (Management Association, Information Resources, 2018). In fact, inadequate fruit and vegetable intake was reported to be the cause of an estimated 3.9 million deaths worldwide in 2017 (Owolade et al, 2017). 
Hence, proper consumption of fruits and vegetables is needed, as it can reduce the risk of cardiovascular diseases, stomach cancer, and colorectal cancer (Slavin \& Lloyd, 2012). This is due to the benefits provided by many natural antioxidants that exist in fruits and vegetables. These compounds protect food from rancidity, as well as reduce oxidative damage in humans (Chiosa et al., 2005). Among all the natural antioxidants, $\beta$ - carotene is known for its benefits in the inhibition of initial stages of lipid peroxidation as well as play a protective role against cancer (Chiosa et al., 2005).

One of the fruits and vegetables that contains high $\beta$-carotene is the orange-fleshed sweet potato (OFSP). Many studies have reported high $\beta$-carotene in OFSP, besides other nutritional elements including carbohydrate, vitamins, protein and minerals. Considering offers by OFSP, this crop holds great potential to be utilised into various food forms in various market segments. Sweet potato can be utilised to make a healthy juice, while the flesh/pulp can be used to make flour for bread and pastries which can cater to celiac disease patients (non-gluten tolerance) (Gaesser \& Angadi, 2015). Detailed exploration and processing of sweet potato are needed in order to have OFSP juice to be considered as a healthy juice drink. A thorough nutrient and proximate analysis should have been performed in order to determine the potential of OFSP juice. To the best of the authors' knowledge, there is very limited information on detailed nutrient composition analysis of local sweet potato juice. Hence, this study is aimed to conduct a nutritional compositional study of the orange-fleshed sweet potato juice. Details of each nutrient are thoroughly discussed.

\section{Materials and Methods}

\subsection{Preparation of OFSP}

Fresh OFSP was purchased from the Malaysian Agricultural Research and Development Institute (MARDI) farm in Bachok, Kelantan, Malaysia. Tubers were stored in the chiller at a temperature of $10^{\circ} \mathrm{C}$ before the subsequent analyses. The tubers were washed with clean running tap water and finally rinsed with distilled water to remove dirt and soil before they were air-dried at room temperature. Once dried, tubers were carefully and manually peeled and cut into small pieces. The small cuts of peeled tubers were pressed using juice extractor (PSN-MJ70M, Panasonic, Malaysia) with a ratio 1:1 (w/w) of water and tuber samples. The pressed samples were ground using a wet mill (MX-SM1031S, Panasonic, Malaysia) and filtered through a cloth filter (mesh size 200) in order to separate crude juice and fibre residues prior to centrifuge (Hettich ${ }^{\circledR}$ Universal 320/320R Centrifuge, Andreas Hettich $\mathrm{GmbH} \& \mathrm{Co}$. KG, Germany) for five minutes at $2500 \mathrm{rpm}$. The obtained supernatants were considered as the OFSP juice and were stored at $-20^{\circ} \mathrm{C}$ until further analysis. The whole OFSP juice preparation steps are shown in Figure 1 below. 


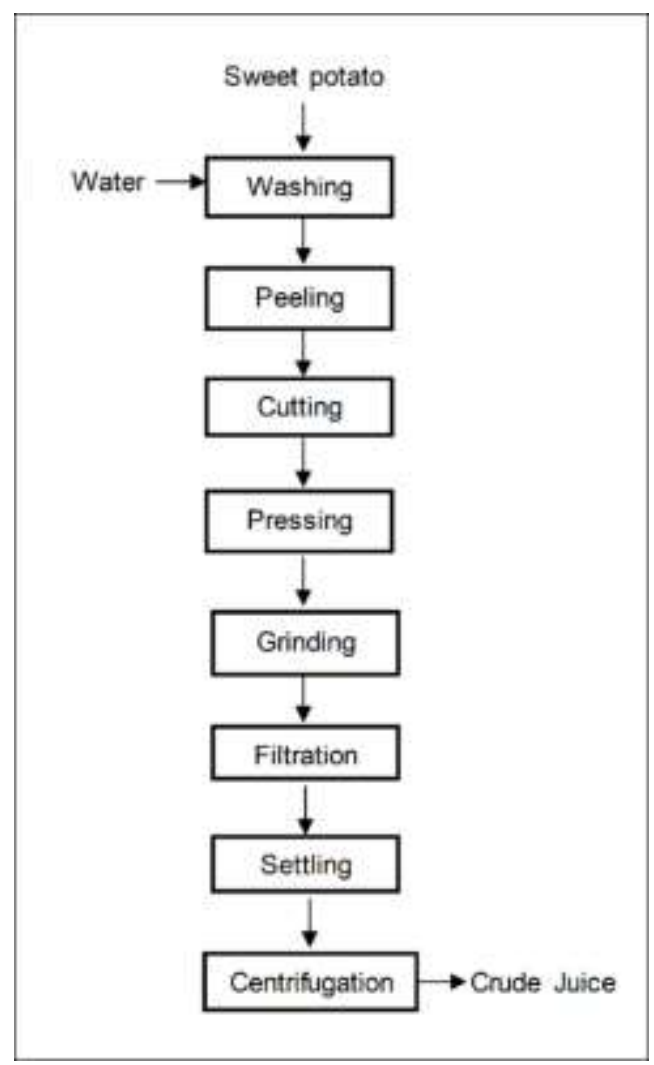

Figure 1. OFSP juice preparation steps

\subsection{Proximate Analysis and Total Starch of OFSP Juice}

OFSP juice was analysed for moisture content in an oven (Memmert, Germany) through the drying method at $105^{\circ} \mathrm{C}$ according to the procedure described in AOAC (1995). Crude fibre was determined according to AACC (2000) using Fibertec ${ }^{\text {TM }} 2010$ (Denmark). Crude fat was determined using Soxtec Extraction (Soxtec ${ }^{\text {TM }}$ 2050, Denmark) for 24 hours. Crude protein content was tested by Kjeltec ${ }^{\mathrm{TM}} 2300$, Denmark which involved protein digestion and distillation according to the Kjeldahl's method (FOSS Analytical AB., 2003). The ash was determined as a total inorganic matter by incineration of the samples at $600^{\circ} \mathrm{C}$ according to the method (AOAC., 1995). Total carbohydrate content was calculated by using the formula as Eq. (1):

Carbohydrate $(\%)=\mathbf{1 0 0}-(\%$ crude protein $+\%$ crude fibre $+\%$ total ash + $\%$ crude fat)

Total energy content was obtained using Eq. (2), Atwater conversion factors 4, 9 and 4 for each gram of crude protein, crude fat and carbohydrate and expressed in calories, respectively (Dako et al., 2016). 


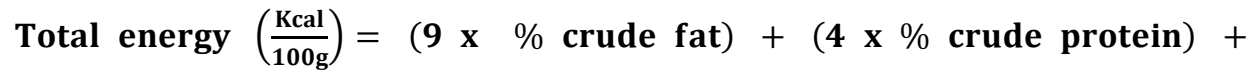
(4 $\times$ total carbohydrate)

Total starch content was determined by using UV-spectrophotometer (Ultrospec 3100 pro, Amershampharmacia Biotech, United Kingdom) read at 580nm (Xiao, Storms \& Tsang, 2006).

\subsection{Ascorbic Acid, Thiamine and Riboflavin Content}

The determination of ascorbic acid was carried out by high-performance liquid chromatography (HPLC) (1100 Series, Agilent, Waldbronn, Germany). The samples were diluted with $4.5 \%$ metaphosphoric acid. Chromatographic separation was achieved on a reversed phase high-performance liquid chromatography (RP-HPLC) (Agilent ZORBAX Eclipse Plus C18, Munich, Germany) column through isocratic delivery of a mobile phase (A/B 33/67; A: 0.1M potassium acetate, $\mathrm{pH}=4.9$, B: acetonitrile: water [50:50]) at a flow rate of $1 \mathrm{~mL} / \mathrm{min}$. UV absorbance was recorded at $254 \mathrm{~nm}$ at room temperature.

Then, thiamine and riboflavin content were determined by RP-HPLC column (Agilent ZORBAX Eclipse Plus C18, Munich, Germany; $250 \times 4.6 \mathrm{~mm} ; 5 \mu \mathrm{m}$ ) through the isocratic delivery mobile phase (A/B 33/67; A: $\mathrm{MeOH}, \mathrm{B}: 0.023 \mathrm{M} \mathrm{H}_{3} \mathrm{PO}_{4}, \mathrm{pH}=3.54$ ) at a flow rate of $0.5 \mathrm{~mL} / \mathrm{min}$. Ultraviolet (UV) absorbance was recorded at $270 \mathrm{~nm}$ at room temperature.

\subsection{Total $\beta$-carotene Content}

The $\beta$-carotene determination was carried out by dissolving samples in $95 \%(\mathrm{v} / \mathrm{v})$ acetone. The supernatant was filtered using filter paper (Whatman filter paper grade 1) before being read with UV-Vis spectrophotometer at absorbance of 449nm (Biswas et al., 2011). The concentration of $\beta$-carotene can be calculated using Beer-Lambert law as in Eq. (3):

$$
\mathrm{A}=\varepsilon \mathrm{cl}
$$

Where $\mathrm{A}$ is the absorbance; $\mathrm{c}$ represents the concentration of carotene; $\varepsilon$ is extinction coefficient; $\mathrm{l}$ is the thickness of cuvettes (path length) $1 \mathrm{~cm}$; the $\varepsilon$ of $\beta$-carotene extract using acetone is $134 \times 103 \mathrm{Lmol}^{-1} \mathrm{~cm}^{-1}$, while $536.88 \mathrm{~g} / \mathrm{mol}$ of $\beta$-carotene molecular weight.

\subsection{Determination of Amino Acids Content}

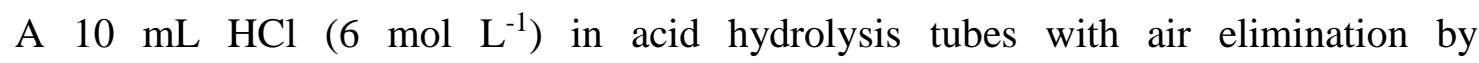
nitrogen-blowing at $110^{\circ} \mathrm{C}$ for $24 \mathrm{~h}$ was hydrolysed with $160 \mathrm{~mL}$ of sample. The hydrolyte was diluted with ultrapure water to $50 \mathrm{~mL}$ after cooling, filtering and washing processes. Then, $1 \mathrm{~mL}$ diluent was placed in a bottle, dried with nitrogen flow and redissolved with 1 $\mathrm{mL} \mathrm{HCl}\left(0.02 \mathrm{~mol} \mathrm{~L}^{-1}\right)$. For further analyses, the solutions were passed through 0.02 -mesh 
filter membranes. The amino acid composition of the samples was measured using amino acids automatic analyser (L-8900, Hitachi Ltd., Tokyo, Japan).

\subsection{Determination of Mineral Elements Content}

$0.25 \mathrm{~mL}$ of sample was measured into a polytetrafluoroethylene digestion tube and $8 \mathrm{~mL}$ $65 \%(\mathrm{v} / \mathrm{v}) \mathrm{HNO}_{3}$ was added for pre-digestion. After 1 hour, $30 \%(\mathrm{v} / \mathrm{v}) \mathrm{H}_{2} \mathrm{O}_{2}$ was added and digested using a microwave digestion system (MARS 5, CEM Co., Matthews, NC, USA). The digested solution was diluted to $100 \mathrm{~mL}$ with Milli-Q water (Bedford, MA, USA) and stored in plastic tubes at $4^{\circ} \mathrm{C}$ for further analysis. Inductively Coupled Plasma Mass Spectrometry (ICP-MS, 7700X; Agilent, USA) was used to measure twelve mineral elements at the operating conditions as such; cooling gas flow rate, $1.47 \mathrm{~L} / \mathrm{min}$; radio frequency power, $1280 \mathrm{~W}$; auxiliary gas flow rate, $1 \mathrm{~L} / \mathrm{min}$, carrier gas flow rate, $1 \mathrm{~L} / \mathrm{min}$; nebulization chamber temperature, $20^{\circ} \mathrm{C}$; and sampling depth, $8 \mathrm{~mm}$.

\section{Results}

\subsection{Proximate Analysis}

Table 1 displays the proximate properties of OFSP juice. For the purpose of comparison with a more established fresh juice, the properties of orange juice reported by Yarkwan \& Oketunde, (2016) are also being listed in Table 1. Based on Table 1, the moisture content of OFSP was recorded at $89.76 \%$, almost similar to orange juice, indicating that OFSD juice in this study is comparable with the more established juice.

The crude fibre content of OFSP juice is displayed in Table 1. According to Table 1, the crude fibre content of OFSP juice was more than 175 times higher (3.49\%) as compared to orange juice $(0.02 \%)$. This finding shows the potential of OFSP juice to be promoted as a healthy drink since high fibre drink can be a source of energy for the human body while preventing constipation and reducing heart disease and diabetes (Rose \& Vasanthakaalam, 2011; Alam et al., 2016). Meanwhile, the crude fat of OFSP juice content was recorded as $1.13 \%$, ten times higher than orange juice $(0.120 \%)$ as shown in Table 1 . This finding is in contrast with another study on the fat content of SP tuber which was reported at $0.2 \%$ (Alam et al., 2016), that might be due to the properties alteration by processing variation.

Based on Table 1, the crude protein content of OFSP juice is $0.39 \%$ which is close to the protein content in orange juice $(0.35 \%)$. The presence of protein in the OFSP juice signifies the existence of valuable essential amino acids which are important for the metabolism process in the human body. Hence, this could justify the potential of the OFSP juice as a healthy juice. Ash content of OFSP is shown as $0.68 \%$ (Table 1), much lower than orange juice in a range of $0.040-0.045 \%$. This high value of ash content indicates a good measure of minerals preserved in juices (Rose \& Vasanthakaalam, 2011). Low ash content in OFSP juice might be attributed to the solids extraction and processing process performed on the tubers during the samples preparation (Figure 1). 
The total carbohydrate content of OFSP juice was determined at $5.04 \%$ which also reflects its energy content of $29.45 \mathrm{Kcal} / 100 \mathrm{~g}$ (Table 1 ). The carbohydrates are an important source of energy in human diets comprising some 40-80\% of total energy intake (FAO/WHO, 1998). An optimum diet for all ages (except for children under the age of two) should consist of at least $55 \%$ of total energy from a variety of carbohydrate sources (FAO/WHO, 1998). In comparison, orange juice has a higher total carbohydrate and energy content. Nevertheless, OFSP juice can still provide energy supply for the human diet. This is proven by the amount of starch content of OFSP juice which is at $1.27 \%$ (Table 1). High starch content in the juice can be manipulated in many food applications such as for dessert and beverages.

Table 1. Proximate analysis of fresh juice.

\begin{tabular}{lcc}
\hline Proximate Analysis & OFSP juice & Orange juice \\
\hline Moisture (\%) & $89.76 \pm 0.11$ & $86.00-86.50$ \\
Crude Fibre (\%) & $3.49 \pm 0.19$ & 0.020 \\
Crude Fat $(\%)$ & $1.13 \pm 0.03$ & 0.120 \\
Crude Protein $(\%)$ & $0.39 \pm 0.03$ & $0.35-0.39$ \\
Ash $(\%)$ & $0.68 \pm 0.02$ & $0.040-0.045$ \\
Total Carbohydrate $(\%)$ & $5.04 \pm 0.27$ & $13.09-13.56$ \\
Starch $(\%)$ & $1.27 \pm 0.11$ & - nd- \\
Total Energy (Kcal/100g) & $29.45 \pm 1.07$ & $54.84-56.88$ \\
\hline
\end{tabular}

\subsection{Ascorbic Acid, Thiamine and Riboflavin, and $\beta$-carotene Content}

Table 2 shows the vitamin composition of OFSP juice in this study as compared to orange juice reported by other studies. Based on Table 2, the OFSP juice contains 0.04 $\mathrm{mg} / 100 \mathrm{~g}$ thiamine and $0.12 \mathrm{mg} / 100 \mathrm{~g}$ riboflavin reflecting the presence of vitamin $\mathrm{B}$ components in the juice. Vitamin B plays a role in the growth of the body as well as for lesions treatment (Ragunatha et al., 2014). Meanwhile, vitamin C in the OFSP juice is 3.73 $\mathrm{mg} / 100 \mathrm{~g}$ as shown in Table 2 which is in the lower range compared to the vitamin $\mathrm{C}$ in orange juice, 8 - $10 \mathrm{mg} / 100 \mathrm{~g}$ (Yarkwan \& Oketunde, 2016). Although the value of ascorbic acid of OFSP juices is considered low, the value is still appreciable to provide health benefits to consumers. The recommended daily amount for vitamin $\mathrm{C}$ is 20 to 90 milligrams $(\mathrm{mg}) \mathrm{a}$ day, and the upper limit is 2,000 mg a day (German Nutrition Society (DGE), 2015). Besides, the content of vitamin $\mathrm{C}$ in the juice might be affected by an oxidation process during the juice preparation. Interestingly, the amount of $\beta$-carotene in OFSP juice sample was 4916.06 $\mu \mathrm{g} / \mathrm{L}$ (Table 2), which is 92 times higher compared to orange juice ranging from 53-69 $\mu \mathrm{g} / \mathrm{L}$ 
reported by Chiosa et al. (2005). This is expected as many studies have reported about the high $\beta$-carotene content in orange-fleshed sweet potato (Mamo et al., 2014; Rodrigues et al., 2016). $\beta$-carotene provides many health benefits such as to alleviate vitamin A deficiency which is good for children under age six (Rodrigues et al., 2016). Moreover, vitamin A also helps in preventing night blindness (Alam et al., 2016). By considering these benefits, OFSP juice can be promoted as a $\beta$-carotene-rich drink and can be marketed in the healthy beverages segment. The potential market of healthy beverages segment has been discussed by Mamo et al., (2014), where the demand for high vitamin content drinks including $\beta$-carotene is expected to increase by $20 \%$ in the next five years. Hence, promoting OFSP juice in this segment is a wise choice.

Table 2. Vitamin composition of fresh juice.

\begin{tabular}{lc}
\hline \multicolumn{1}{c}{ Vitamins } & OFSP juice \\
\hline Vitamin B1 (Thiamine) $(\mathrm{mg} / 100 \mathrm{~g})$ & $0.04 \pm 0.18$ \\
Vitamin B2 (Riboflavin) $(\mathrm{mg} / 100 \mathrm{~g})$ & $0.12 \pm 0.03$ \\
Vitamin C (Ascorbic acid) $(\mathrm{mg} / 100 \mathrm{~g})$ & $3.73 \pm 0.06$ \\
$\beta$-carotene $(\mu \mathrm{g} / \mathrm{L})$ & $4916.06 \pm 0.73$ \\
\hline
\end{tabular}

*Data are mean values \pm standard deviation.

\subsection{Amino acids Content}

Table 3 exhibits the amino acids content of OFSP juice. Based on Table 3, histidine, arginine and aspartic content $(0.50 \%, 0.42 \%$ and $0.20 \%)$ were recorded higher as compared to other types of amino acids. The other amino acid content such as glycine, isoleucine, alanine, lysine, glutamic, leucine, methionine, tyrosine, phenylalanine, serine, threonine and valine were found to be at lower content ranging from $0.01 \%$ until $0.09 \%$. However, cysteine and proline were not detected from the analysis. Mohanty et al., (2014) has discussed the role of each amino acid in detail including the roles of histidine in the protein interaction and is also a precursor of histamine. Besides, histidine is important for the repair of tissues and growth, for maintaining the myelin sheaths, and for the removal of heavy metals from the body. Meanwhile, arginine is needed in cell division, ammonia removal, immune function, wound healing and hormone release (Mohanty et al., 2014). It also plays important roles in neurotransmission, maintenance of blood pressure and blood clotting which is the precursor for biological synthesis of nitric oxide. In addition, arginine is also essential for the recovery of a few diseases like hypertension, erectile dysfunction, sepsis, preeclampsia and anxiety. As amino acid deficiencies lead to several diseases, knowledge of its composition in foods is important as it will affect the preparation, processing and storage of foods and use as dietary guidance for healthy drink production. 
Table 3. Amino acids content of juice.

\begin{tabular}{|c|c|}
\hline Amino Acids (\%) & OFSP juice \\
\hline Alanine & $0.06 \pm 0.31$ \\
\hline Lysine & $0.05 \pm 0.12$ \\
\hline Arginine & $0.42 \pm 0.65$ \\
\hline Aspartic & $0.20 \pm 0.88$ \\
\hline Cystine & -nd- \\
\hline Glutamic & $0.09 \pm 0.45$ \\
\hline Glycine & $0.04 \pm 0.23$ \\
\hline Histidine & $0.50 \pm 0.11$ \\
\hline Isoleucine & $0.04 \pm 0.07$ \\
\hline Leucine & $0.06 \pm 0.32$ \\
\hline Methionine & $0.01 \pm 0.48$ \\
\hline Phenylalanine & $0.05 \pm 0.01$ \\
\hline Proline & -nd- \\
\hline Serine & $0.04 \pm 0.17$ \\
\hline Threonine & $0.04 \pm 0.05$ \\
\hline Tyrosine & $0.03 \pm 0.06$ \\
\hline Valine & $0.06 \pm 0.33$ \\
\hline
\end{tabular}

*Data are mean values \pm standard deviation.

\subsection{Mineral Element Content}

Table 4 represents the mineral element composition of the OFSP juice compared to orange juice as reported by Yarkwan \& Oketunde, (2016). The OFSP juice contains 147.77 $\mathrm{mg} / 100 \mathrm{~g}$ of potassium, $30.06 \mathrm{mg} / 100 \mathrm{~g}$ of sodium, $10.03 \mathrm{mg} / 100 \mathrm{~g}$ of calcium, and 0.79 $\mathrm{mg} / 100 \mathrm{~g}$ of iron which are higher as compared to orange juice, as shown in Table 4 . The role of calcium is good for humans in particular cell physiology, mineralisation of bone and in making the teeth and bone very strong. Meanwhile, iron helps in transporting oxygen in the blood. In human diets, these minerals are important micronutrients (Danish et al., 2019). 
Besides, the other mineral element composition of OFSP juice such as phosphorus (44.74 mg/100 g), sulphur (32.66 mg/100 g), magnesium $(32.64 \mathrm{mg} / 100 \mathrm{~g})$, zinc $(0.57$ $\mathrm{mg} / 100 \mathrm{~g})$, manganese $(0.31 \mathrm{mg} / 100 \mathrm{~g})$, aluminium $(0.30 \mathrm{mg} / 100 \mathrm{~g})$, copper $(0.17 \mathrm{mg} / 100$ $\mathrm{g})$, and boron $(0.15 \mathrm{mg} / 100 \mathrm{~g})$ were determined in Table 4 . Subsequently, the appropriate Recommended Dietary Allowance (RDA) or adequate intake (AI), AI for females and males aged $31-50$ is $1500 \mathrm{mg} /$ day (sodium), $1000 \mathrm{mg} /$ day (calcium) and $4700 \mathrm{mg} /$ day (potassium) (Yarkwan \& Oketunde, 2016; Koubová et al., 2018). Iron has an RDA value of $8 \mathrm{mg} / \mathrm{day}$ and $18 \mathrm{mg} /$ day for average men and women aged 31-50 respectively (Yarkwan \& Oketunde, 2016; Koubová et al., 2018). Thus, in reference to the AI and RDA, OFSP juice can provide high minerals to the consumers in order to cater to the required intake.

Table 4. Mineral element composition of fresh juice.

\begin{tabular}{|c|c|c|}
\hline Minerals (mg/100g) & OFSP juice & Orange juice \\
\hline Phosphorus & $44.74 \pm 0.13$ & -nd- \\
\hline Potassium & $147.77 \pm 0.09$ & $0.0181-0.021$ \\
\hline Sulphur & $32.66 \pm 0.02$ & -nd- \\
\hline Aluminium & $0.30 \pm 0.33$ & -nd- \\
\hline Calcium & $10.03 \pm 0.15$ & $0.0046-0.0048$ \\
\hline Magnesium & $32.64 \pm 0.11$ & -nd- \\
\hline Manganese & $0.31 \pm 0.46$ & -nd- \\
\hline Iron & $0.79 \pm 0.04$ & $0.0012-0.0014$ \\
\hline Copper & $0.17 \pm 0.18$ & -nd- \\
\hline Zinc & $0.57 \pm 0.01$ & -nd- \\
\hline Boron & $0.15 \pm 0.03$ & -nd- \\
\hline Sodium & $30.06 \pm 0.22$ & $0.0052-0.0053$ \\
\hline
\end{tabular}

\section{Conclusion}

Based on the proximate analysis, vitamins, amino acids and mineral composition, OFSP juice shows a promising potential to be an alternative for a healthy drink. The highlight of the juice composition was the high content of $\beta$-carotene, which can provide many health benefits including prevent anti-mutagenic, immuno-enhancers, cancers and free radical 
scavengers. Besides the vitamins, amino acids and mineral content of the OFSP juice are also considered sufficient to partly cater to the recommended daily intake of consumers.

Acknowledgments: Authors are thankful to the staff technician laboratory, Department of Processing and Food Engineering, Faculty of Engineering, for their considerable help to complete this research successfully.

Funding: The research was supported by GP-IPB/2018/9660302, University Putra Malaysia (UPM), Serdang, Selangor, Malaysia is acknowledged

Conflicts of Interest: The authors declare no conflict of interest, and also the funders had no role in the collection, analyses, or interpretation of data; design of the study; in the writing of the manuscript, or in the decision to publish the results.

\section{References}

Alam, M., Rana, Z., \& Islam, S. (2016). Comparison of the Proximate Composition, Total Carotenoids and Total Polyphenol Content of Nine Orange-Fleshed Sweet Potato Varieties Grown in Bangladesh. Foods, 5(4): 64.

AOAC. (1995). Association of Official Analytical Chemist. Official methods of analysis, 17th edition. Washington, DC.

AACC. (2000). Approved Methods of the American Association of Cereal Chemists, Vol. 1(Method No. 30-25, 44-15A), USA: American Association of Cereal Chemists.

Biswas, A. K., Sahoo, J., \& Chatli, M. K. (2011). A simple UV-Vis spectrophotometric method for determination of $\beta$-carotene content in raw carrot, sweet potato and supplemented chicken meat nuggets. LWT - Food Science and Technology, 44(8): 1809-1813.

Chiosa, V., Mandravel, C., Kleinjans, J. C. S., et al. (2005). Determination of B-Carotene Concentration in Orange and Apple Juice and in Vitamin Supplemented Drinks. Analele UniversităŃii din Bucuresti - Chimie, Anul XIV (serie nouă:, Vol. I-II, 253-258.

Dako, E., Retta, N., \& Desse, G. (2016). Comparison of Three Sweet Potato (Ipomoea Batatas (L.) Lam) varieties on Nutritional and Anti-Nutritional Factors. Global Journal of Science Frontier Research: D Agriculture and Veterinary. 16(4): 63-71.

Danish, A.Z., Rozaihan, M., Mohd, M.M.A., et al. (2019). Differentiation of Malaysian Farmed and Commercialised Edible Bird's Nests through Nutritional Composition Analysis. Pertanika J. Trop. Agric. Sc. 42(3): 871-881.

FAO/WHO (1998). Carbohydrate in Human Nutrition. Report of a Joint Expert FAO/WHO Consultation. FAO Food and Nutrition Paper 66. Food and Agriculture Organization, Rome. 140 p.

Foss Analytical AB. (2003). Manual for Kjeltec System 2300 Distilling and Titration Unit.

Gaesser, G.A., \& Angadi, S.S. (2015). Navigating the gluten-free boom. Journal of American Academy of Physician Assistants, 28(8): 1-8.

German Nutrition Society (DGE) (2015). New Reference Values for Vitamin C Intake. Ann Nutr Metab, 67:13-20. doi: 10.1159/000434757. 
Koubová, E., Sumczynski, D., Šenkárová, L., et al. (2018). Dietary Intakes of Minerals, Essential and Toxic Trace Elements for Adults from Eragrostis tef L. A Nutritional Assessment. Nutrients, 10(4): 479.

Mamo, T.Z., Mezgebe, A.G., \& Haile A. (2014). Development of orange-fleshed sweet potato (Ipomoea batatas) juice: Analysis of physico-chemical, nutritional and sensory property. International Journal of Food Science and Nutrition Engineering, 4(5): 128-137.

Management Association, Information Resources. (2018). Food Science and Nutrition: Breakthroughs in Research and Practice: Breakthroughs in Research and Practice. Book. IGI Global, Medical.

Mohanty, B., Mahanty, A., Ganguly, S., et al. (2014). Amino Acid Compositions of 27 Food Fishes and Their Importance in Clinical Nutrition. Journal of Amino Acids. 7.

Owolade, S.O., Akinrinola, A.O., Popoola, F.O., et al. (2017). Study on physico-chemical properties, antioxidant activity and shelf stability of carrot (Daucus carota) and pineapple (Ananas comosus) juice blend. International Food Research Journal, 24(2): 534-540.

Ragunatha, S., Kumar, J.V., Murugesh, S.B., et al. (2014). Therapeutic Response of Vitamin A, Vitamin B Complex, Essential Fatty Acids (EFA) and Vitamin E in the Treatment of Phrynoderma: A Randomized Controlled Study. Journal of Clinical Diagnostic Research, 8(1): 116-118.

Rodrigues, N. da R., Barbosa Junior, J.L., \& Barbosa, M.I.M.J. (2016). Determination of physico-chemical composition, nutritional facts and technological quality of organic orange and purple-fleshed sweet potatoes and its flours. International Food Research Journal, 23(5): 2071-2078.

Rose, I. M., \& Vasanthakaalam, H. (2011). Comparison of the Nutrient composition of four sweet potato varieties cultivated in Rwanda. American Journal of Food and Nutrition, 1(1): 34-38.

Slavin, J. L., \& Lloyd, B. (2012). Health Benefits of Fruits and Vegetables. Advances in Nutrition, 3(4): 506-516.

Xiao, Z., Storms, R., \& Tsang, A. (2006). A quantitative starch-iodine method for measuring alpha-amylase and glucoamylase activities. Analytical Biochemistry, 146-149.

Yarkwan, B., \& Oketunde, O. (2016). A Study of the Nutritional Composition of Freshly Squeezed and Processed Orange Juices. Food Science and Quality Management, 48, 126-132.

Copyright (C 2020 by Zulkifli NA et al. and HH Publisher. This work is licensed under the Creative Commons Attribution-NonCommercialNon-commercial 4.0 International LisenceLicence (CC-BY-NC4.0) 